\title{
高速液体クロマトグラフィーによる蓚酸測定
}

\author{
帝京大学医学部附属市原病院泌尿器科 \\ 伊藤 晴夫 小竹 忠 鈴木 文夫 林 裕子 \\ 横浜労災病院泌尿器科 \\ 山 口 邦 雄
}

\section{DETERMINATION OF OXALIC ACID BY HIGH PERFORMANCE LIQUID CHROMATOGRAPHY}

\author{
Haruo Ito, Tadashi Kotake, Fumio Suzuki and Hiroko Hayashi \\ Department of Urology, Teikyo University School of Medicine, Ichihara Hospital \\ Kunio Yamaguchi \\ Department of Urology, Yokohama Rosai Hospital
}

In order to determine a reliable method for measuring oxalic acid, we carried out a procedure using high performance liquid chromatography. This method proved to be excellent in the case of tea and beer. In the case of urine, however, it had some problem from the aspect of reproducibility, although as far as linearity measurement, dilution test and recovery rate were concerned, accurate results could be obtained. Nevertheless, this method was thought to be unsuitable for routine clinical use, at least at present, for the reasons that it took a long time to perform the measurement, and because of the high cost of the column used in the procedure.

The value of the oxalic acid as determined by this method in $24 \mathrm{hr}$ urine from 12 healthy male volunteers was in the range of $17-47 \mathrm{mg} /$ day (average \pm standard deviation: $25.4 \pm 9.0$ ). To correct for their differences of physical constitution, dividing exalic acid value by body weight rather than by urinary creatinine or body surface area was found to give a more precise value of the norm. From this calculation, it was thought that the normal range of oxalic acid value was $0.6 \mathrm{mg} / \mathrm{kg}$ or less.

Key words: oxalic acid determination, urinary oxalic acid, high performance liquid chromatography

\footnotetext{
要旨：蓚酸の良い測定法を見出すために，高速液体クロマトグラフィーによる方法についての検討を 行った.
}

高速液体クロマトグラフィーによる方法は茶, ビールに対しては, これらの成分に蓚酸と retention time の近い物質が少ないので, ピークの分離がよく, 操作も複雑で無いので, きわめて良い方法である. 尿に拉いては測定の直線性, 希釈試験, 回収率では良い結果が得られたが, 再現性においてはやや問題 がある，本法は，研究用に少数の検体を測定するには向いているが，測定に時間がかかること，カラム が高価なため, ルーチンの臨床検査には適していない。

本法により測定した 12 人の健康対照人の一日尿中の蓚酸量は $16 \sim 47 \mathrm{mg}$ (平均士標準偏差 : $25.4 \pm 9.0$ ) であった。体格の違いを補正するために蓚酸量を尿中クレアチニン, 体表面積, あるいは体重で割ると, 後者の変動係数がもっとも小さかった。したがって，体格の違いを補正するには蓚酸量を体重で割るの が良く，この場合の正常範囲は体重（kg）あたり $0.6 \mathrm{mg}$ 以下とするのが良いと思われた. キーワード：苳酸測定, 尿中蓚酸, 高速液体クロマトグラフィー

\section{緒言}

尿路結石の大部分は蓚酸カルシウムを主成分として いる1. 苳酸カルシウムの supersaturation に対して,
尿中蓚酸の濃度はカルシゥム濃度よりはるかに強い影

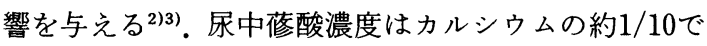
ありまた，カルシウムと苳酸は可溶性の複合体をあ 
る程度形成する。このため, 蓚酸のわずかな変化は蓚 酸カルシウム飽和度に重大な影響を掞よぼすが，カル シウムの変化はあまり影響しない4)，尿中蓚酸濃度が 上昇すると葆酸カルシウム結晶濃度が上昇するが, 葆 酸濃度が $45 \mathrm{mg} / l$ を越えると, 結晶濃度が急激に上昇 する5). 正常範囲よりもわずかに高いだけで, 強い影響 を与える。このように，尿中蓚酸が，蓚酸カルシウム 結石形成にきわめて重要な役割を演じているので, mild hyperoxaluria と表現されるよらな蓚酸の尿中 への軽度の排泄増加は重大な意味を持つ6).

苳酸カルシウム結石形成に打いては尿中の蓚酸カル シウム結晶の成長を抑制する物質 (inhibitor) ${ }^{7)}$ も重要 であり,この点はシスチン ${ }^{8)}$, 尿酸, リン酸・アンモニ ウム・マグネシウム結石がその尿中濃度と尿 $\mathrm{pH}$ とで ほぼ結石形成が起こるかどうか決まるのと異なる。

以上より，尿中蓚酸の測定は正確でなければならな いことがわかる ${ }^{9)}$. 蓚酸の測定法には種々の問題点が あり，多くの方法が報告されている ${ }^{9}$. 理想的なものは ないのが現状であるが，蓚酸分解酵素を用いる方法あ るいは高速液体クロマトグラフィー（HPLC)を用いる 方法が良いとする論文もある ${ }^{10111}$. 酵素法にも欠点が あり，また，HPLCに関する最近の進歩には著しいも のがあるので, 今回, HPLCによる測定について検討 をおこなった。

\section{対象と方法}

HPLC による茶・ビールの中の蓚酸測定

ビールは国産 4 社 5 銘柄および外国産 2 社 2 銘柄に ついて測定した。試料は超音波洗浄器を使い吸引脱気 の後, 蒸留水で 5 倍希釈し, 前処理用の TOYOPAK IC-SP (H 型) に通した。

茶は烏龍茶 6 社 7 銘柄, 緑茶 2 社 3 銘柄, 紅茶 2 銘 柄，ぞくだみ茶， 泀らじ茶それぞれ 1 銘柄について測 定した。試料は蒸留水で 3 倍希釈し，前処理用の TOYOPAK IC-SP (H 型) に通した.

高速液体クロマトグラフは Tosoh 社8010シリーズ を用いた。前処理後の試料 $100 \mu 1$ を HPLC 装置に注入 する。溶離液は高速イオンクロマトグラフィー用アニ オン標準溶離液（キシダ化学）を超音波洗浄器を使い 吸引脱気したものである.流速は $1.2 \mathrm{ml} / \mathrm{min}$, 圧力は 20

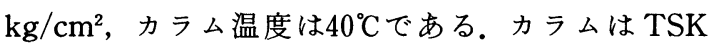
guard column (TOSOH) と TSKgel IC-Anion-PW （TOSOH）を直列につないだものである，カラムはそ の劣化を考慮して15検体で交換した．蓚酸イオンの検 出は electroconductivity detector で行う.定量計算は
図 1 尿の前処理法

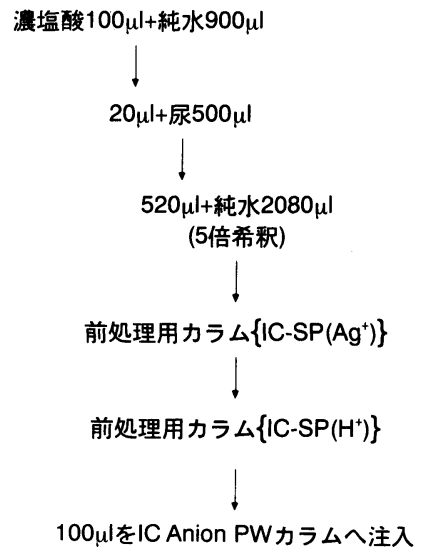

クロマトグラフィー用データ処理装置 (Chromatocorder $12 \mathrm{sic}$ ）を用いて，蓚酸標準液 $100 \mathrm{mg} / l$ を前述の前 処理後, 注入して得たクロマトグラムのピーク面積を 計算し，未知資料のピーク面積との比率から，未知資 料の蓚酸濃度を自動的に算出する。

HPLCによる尿中蓚酸の測定

尿路結石患者扣よび対照健康人の 24 時間蓄尿した尿 中に含まれる蓚酸を測定した。24時間蓄尿は容器にチ モール1gを予め加えておき，第 1 回目の尿を入れたあ とに， $1.5 \mathrm{~N}$ 塩酸 $80 \mathrm{ml}$ を加えるようにした。

前処理は図 1 のごとくに行った.すなわち，尿 $500 \mu 1$ に $1.2 \mathrm{~N}$ の塩酸 $20 \mu \mathrm{l}$ を加兄, 渦動擋找器で 3 分間混和 する. 蒸留水で 5 倍に希釈し, 前処理用のカラム TOYOPAK IC-SP (Ag 型) に通し，さらに TOYOPAK IC-SP (H 型) に通す．前処理が終わった 試料 $100 \mu 1$ を HPLC 装置に注入する.

防腐剤を尿に加えることが，蓚酸測定を阻害するか ぞうかをみた。加えた防腐剤の種類とその最終濃度は

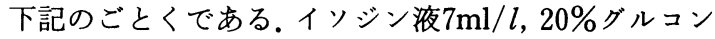
酸クロルヘキシジン液 $1 \mathrm{ml} / l, 5 \%$ グルコン酸クロル ヘキシジン液 $4 \mathrm{ml} / l$, チモール $1 \mathrm{~g} / l$, トルェン $1 \mathrm{ml} / l$, アジ化ナトリウム $1 \mathrm{~g} / l$.

尿中カルシウム， マグネシウム，リンはオートアナ ライザーで測定した（日立 Model 705）.

\section{1）標準曲線}

結 果

蓚酸カリウムで蓚酸の各種濃度の溶液をつくり，尿 検体と同じ前処理を行った後，HPLCで測定した，図 2 に示したごとく，良好な直線性が得られた。 
表 1 尿中苳酸測定値に対する防腐剤添加の影響

\begin{tabular}{l|l|l|l}
\hline 原尿 & $12.3 \mathrm{mg} / l$ & 25.4 & 34.4 \\
ポピドンョード液 $(7 \mathrm{ml} / l)$ 添加 & 16.1 & 24.8 & 39.8 \\
$20 \%$ ル゙ルンン酸クロルヘキシジン $(1 \mathrm{ml} / l)$ 添加 & 16.0 & 17.6 & 22.3 \\
$5 \%$ グルコン酸クロルヘキシジン $(4 \mathrm{ml} / l)$ 添加 & 10.8 & 23.2 & 26.8 \\
チモール $(1 \mathrm{~g} / l)$ 添加 & 13.1 & 21.1 & 38.0 \\
トルェン $(1 \mathrm{ml} / l)$ 添加 & 16.3 & 21.8 & 36.6 \\
アジ化ナトリウム $(1 \mathrm{~g} / l)$ 添加 & 9.6 & 23.9 & 38.8 \\
\hline
\end{tabular}

図 2 検量線

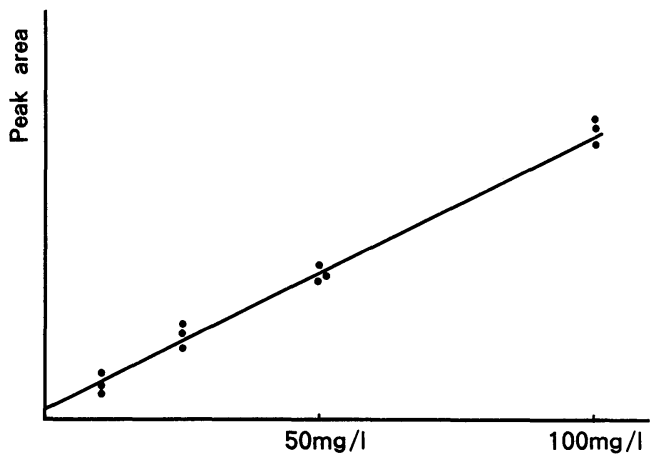

因 3 希釈試験

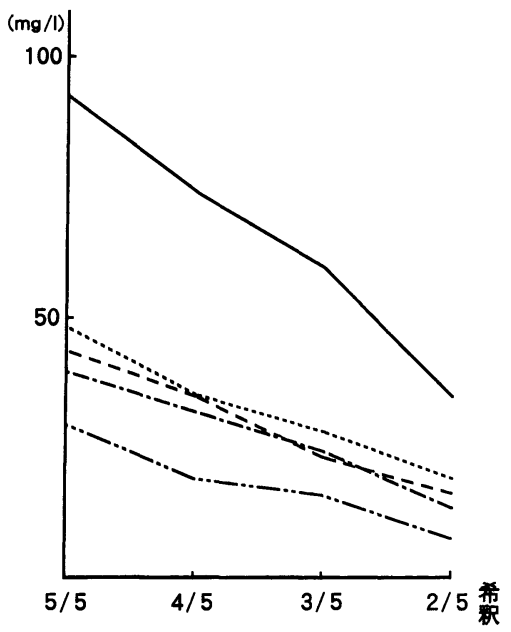

\section{2）防腐剂添加の影響}

各種の防腐剤を加える前後の尿中蓚酸を測定した結 果を表 1 に示した。防腐剤による影響は見られなかっ た.

\section{3）希釈試験}

種々な濃度を示す尿 5 検体を $4 / 5,3 / 5,2 / 5$ に希釈し
表 2 HPLCによる測定值の再現性

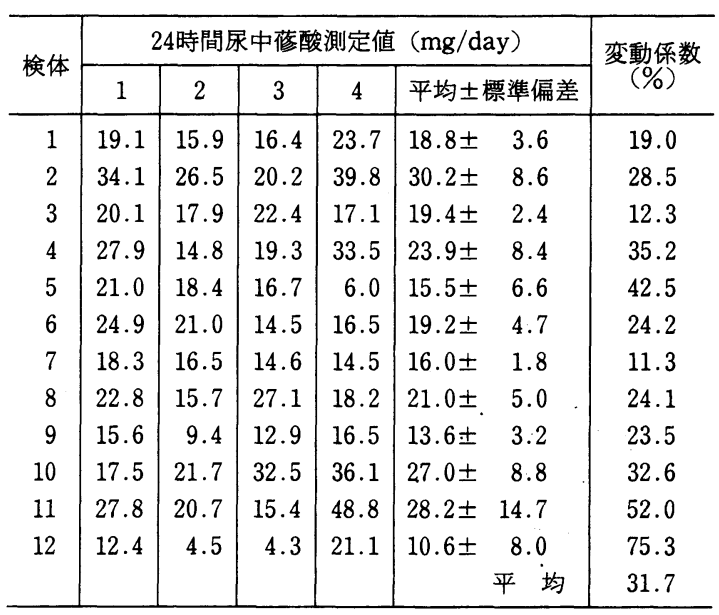

た。それぞれについて，希釈前および希釈後の苳酸濃 度を測定した。図 3 に示したごとく，良い直線性が得 られた。

\section{4）再現性}

12 検体の尿を各々 4 回測定した(表 2 )。变動係数は 11.3 75.3, 平均 31.7 であった。変動係数は平均値を 100 とした場合の標準偏差を示しているので，HPLC による再現性はきわめて良好とは言えなかった。

5）回収率

HPLC 法による回収率を調べるために，5検体の尿 に $25 \mathrm{mg} / l$ 相当分の蓚酸を添加して, 測定した. 加えた

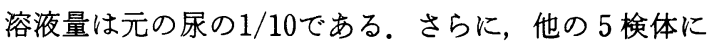
ついて，それぞれ $50 \mathrm{mg} / l, 100 \mathrm{mg} / l$ 相当分の蓚酸を添 加して測定した（表 3 ）。 以上の 3 群の平均回収率は,

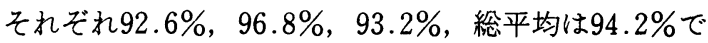
あった。このように，回収率はかなり良好であった。

6）クロマトグラムについて

HPLCで得られる苳酸のピークは茶, ビールの場合 は，他の成分より完全に分離し，きれいに描出される 
表 3 添加回収率

\begin{tabular}{|c|c|c|c|}
\hline \multirow{2}{*}{ 検体 } & \multirow{2}{*}{$\begin{array}{c}\text { 层 } \\
\text { 苳酸量 }(\mathrm{mg} / \mathrm{l})\end{array}$} & \multicolumn{2}{|c|}{$25 \mathrm{mg} / \mathrm{l}$ 蓚酸添加 } \\
\hline & & 測定値(mg) & 回収率(\%) \\
\hline 1 & 33.2 & 57.2 & 96 \\
\hline 2 & 2.6 & 27.3 & 99 \\
\hline 3 & 47.8 & 70.2 & 89 \\
\hline 4 & 12.1 & 36.1 & 96 \\
\hline \multirow[t]{2}{*}{5} & 2.9 & 32.9 & 83 \\
\hline & \multicolumn{2}{|l|}{ 平 } & 92.6 \\
\hline \multirow{2}{*}{ 検体 } & \multirow{2}{*}{$\begin{array}{c}\text { 尿 } \\
\text { 葆酸量 }(\mathrm{mg} / l)\end{array}$} & \multicolumn{2}{|c|}{$50 \mathrm{mg} / \mathrm{l}$ 蓚酸添加 } \\
\hline & & 測定値 (mg) & 回收率(\%) \\
\hline 6 & 21.8 & 72.7 & 102 \\
\hline 7 & 20.1 & 70.7 & 101 \\
\hline 8 & 28.4 & 67.2 & 78 \\
\hline 9 & 18.1 & 71.2 & 106 \\
\hline \multirow[t]{2}{*}{10} & 37.3 & 85.8 & 97 \\
\hline & \multicolumn{2}{|l|}{ 平 } & 96.8 \\
\hline \multirow{2}{*}{ 検体 } & \multirow{2}{*}{$\begin{array}{c}\text { 尿 } \\
\text { 苳酸量 }(\mathrm{mg} / \mathrm{l})\end{array}$} & \multicolumn{2}{|c|}{$100 \mathrm{mg} / l$ 苳酸添加 } \\
\hline & & 測定値 (mg) & 回收率 (\%) \\
\hline 11 & 21.8 & 118.9 & 97 \\
\hline 12 & 20.1 & 116.4 & 96 \\
\hline 13 & 28.4 & 112.2 & 84 \\
\hline 14 & 18.1 & 105.4 & 87 \\
\hline \multirow[t]{3}{*}{15} & 37.3 & 139.2 & 102 \\
\hline & 平 & 均 & 93.2 \\
\hline & 総． & 均 & $94.2 \%$ \\
\hline
\end{tabular}

図 4 HPLCによる茶中の蓚酸量測定におけるクロ マトグラムの 1 例

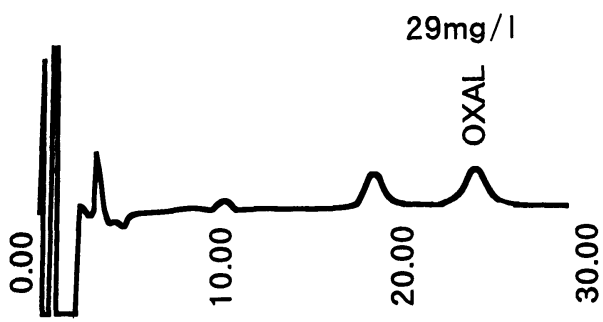

（図 4)，尿の場合にも，ほとんどの場合，他の成分と 良く分離する(図 5 )。しかし，多数の検体を測定して カラムが劣化してくると他成分との分離がうまく行か ない場合がある、また，基線が 0 に戻らないらちに， 蓚酸のピークが始まってしまうことがある(図 6)，さ らに, 尿, 茶, ビールのいずれの場合にも, 蓚酸のピー クはやや幅広であった。これは正確な測定を妨げる一 因となりうることが考えられた。
図 5 HPLCによる尿中苳酸量測定におけるクロマ トグラムの 1 例

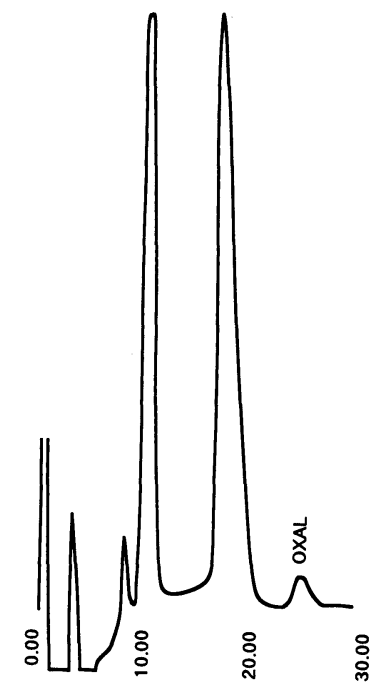

図 6 HPLCによる尿中蓚酸量測定におけるクロマ トグラムの一不良例

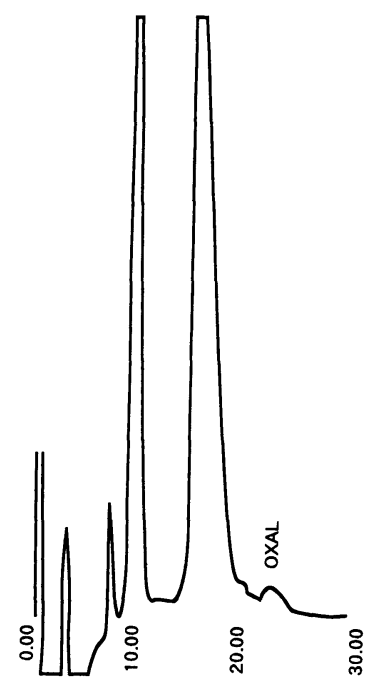

7）対照尿の測定

Sigma 社の尿中蓚酸測定キット ${ }^{12)} に$ 附属している 2 種類の oxalate control urine を測定した。蓚酸濃度 $16 \sim 25 \mathrm{mg} / l$ の control urine の HPLCによる測定值 は $19 \mathrm{mg} / l$, 蓚酸濃度 $86 \sim 126 \mathrm{mg} / l$ のものの測定値は $93 \mathrm{mg} / l$ であり，いずれの值も説明書に記載されてい た範囲内であった. control urine の場合, クロマトグ ラムにおける苳酸のピークはきれいに描出された（図 
7 ).

8）各種の茶, ビール中の蓚酸量

市販の缶入り茶中（表 4) および缶拉よび墂ビール 中（表 5 ）の蓚酸含有量を測定した結果を示した.

9）正常人の尿中苳酸排泄量

尿路結石の既往のない健康男性の 24 時間尿中蓚酸排 泄量は17 47mg/日であった. 通常, 蓚酸排泄量の正常 範囲としては $45 \mathrm{mg} /$ 日以下とされるが13)，これをこす

因 7 Sigma 社の対照尿のクロマトグラム

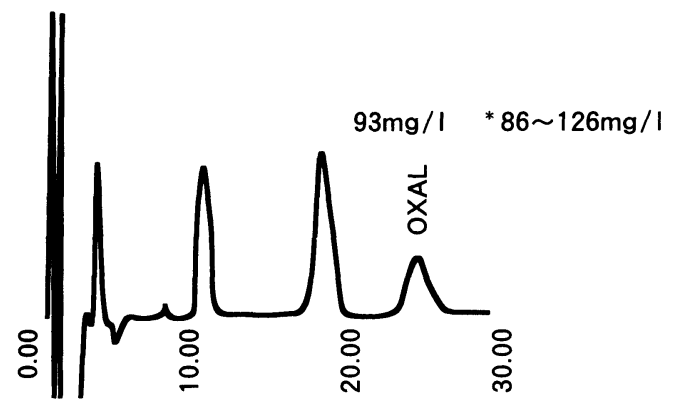

表 4 各種茶中の蓚酸量

\begin{tabular}{cc|c}
\hline 種 & 類 & Oxalate $(\mathrm{mg} / l)$ \\
\hline 烏龍茶 & 1 & 29.5 \\
& 2 & 36.5 \\
& 3 & 31.5 \\
& 4 & 29.0 \\
& 5 & 32.0 \\
& 6 & 26.5 \\
& 7 & 22.5 \\
\hline 緑 茶 & 1 & 52.0 \\
& 2 & 63.5 \\
& 3 & 56.5 \\
\hline 紅 茶 & 1 & 44.0 \\
& 2 & 34.5 \\
\hline ぞくだみ茶 & 88.0 \\
\hline ほうじ茶 & 37.5 \\
\hline
\end{tabular}

表 5 ビール中の蓚酸量

\begin{tabular}{lc|c}
\hline 種 & 類 & Oxalate $(\mathrm{mg} / l)$ \\
\hline ビール & 1 & 21.5 \\
& 2 & 24.3 \\
& 3 & 9.9 \\
& 4 & 14.0 \\
& 5 & 19.4 \\
& 6 & 7.6 \\
& 7 & 15.3 \\
\hline
\end{tabular}

ものは 1 人だけであった。これは体が大きいことで説 明されると思われる。12例の平均土標準偏差は $25.4 \pm$ 9.0であった。体格と蓚酸排泄量との関係をみるため に, 蓚酸排泄量を尿中クレアチニン, 体重, 体表面積 当たりに換算した值を表 6 に示した。これらの変動係 数からわかるように苳酸量を体重 $(\mathrm{kg})$ で割ることが 体格の違いを補正するもっとも良い方法と考元られ た。また，この補正値で見る場合の正常範囲は $0.6 \mathrm{mg} /$ $\mathrm{kg}$ 以下が妥当と思われた.

\section{考 察}

蓚酸は広く自然界に分布している有機酸の一つで化 学的に非常に特異な性質をもっている。 その化学構造 は簡単な 2 塩基酸で, 強酸であり, 化学反応は 1 塩基 酸としても， 2 塩基酸としても反応する. 蓚酸の測定 には種々の困難が伴う。その主なものには, 濃度が低 いときに sensitivity に欠けること, 尿中の他の物質, 特にビタミンCによる阻害, これとは逆にビタミンC が nonenzymatically に莜酸に変化すること, 測定時 間が長いこと, 測定用機器が高価であることなどであ る ${ }^{14)}$. 現在では, とくに正確な測定ができると期待でき るのは酵素法, とくに固定化酵素を用いる方法と HPLC 法とされる ${ }^{11)}$. 酵素法は特異性が高く，また， 多数の検体を処理するのにも適している。しかし，ビ タミンCによる阻害の問題がある ${ }^{15)}$. Kasidas 等の固 定化した oxalate oxidase 用いる方法はビタミンC による阻害を sodium nitrite で除去している.しかし，

表 6 尿中蓚酸量の尿中クレアチニン, 体重, 体表面積による補正

\begin{tabular}{|c|c|c|c|c|c|c|c|c|c|c|c|c|c|}
\hline 尿中蓚酸量およびその補正值 & 1 & 2 & 3 & 4 & 5 & 6 & 7 & 8 & 9 & 10 & 11 & 12 & 変動係数 \\
\hline 苳酸 $(\mathrm{mg} /$ 日 $)$ & 19 & 16 & 31 & 34 & 21 & 25 & 17 & 29 & 20 & 28 & 18 & 47 & $35.7(\%)$ \\
\hline 蓚酸 $(\mathrm{mg}) /$ /クレアチニン $(\mathrm{g})$ & 14 & 10 & 15 & 18 & 13 & 18 & 12 & 7 & 15 & 17 & 11 & 24 & 30.6 \\
\hline$\{$ 苳酸 $(\mathrm{mg} /$ 日) $/$ 体重 $(\mathrm{Kg})\} \times 100$ & 28 & 22 & 35 & 44 & 30 & 31 & 29 & 39 & 33 & 37 & 23 & 56 & 27.4 \\
\hline 蓚酸 $(\mathrm{mg}) /$ 体表面積 $\left(1.73 \mathrm{~m}^{2}\right)$ & 11 & 9 & 15 & 18 & 12 & 13 & 11 & 15 & 12 & 15 & 9 & 23 & 30.4 \\
\hline
\end{tabular}


酵素法のさいのビタミンCによる阻害を防ぐ方法を 検討した Inamdarによれば, この sodium nitrite の防 止効果は不充分といら ${ }^{16)}$. このように, 酵素法にも問題 点がある. HPLC 法は苳酸を発色剂と反応させてから 測定するものと，イオン交換樹脂を通して，イオンと してとらえるものがある。後者のほらが操作が簡便な ので，今回この方法を検討したわけである.

HPLCによるイオンクロマトグラフィーは多数の 検体を一時に処理出来ないこと，カラムが高価である ことを除けばよい方法と考えられた。ピークの分離は 良くない検体も稀にあることは問題である。これを克 服する方法としては次のことがあげられるであろう。 すなわち，前処理により他のイオン，とくに蓚酸の直 前に溶出してくる硫酸イオンを除く，あるいは，まず 蓚酸を含む粗分画を得ることである．前者は難しいと 思われるので，シリカゲル，あるいはその他の物質に 蓚酸を吸着させ，何らかの溶剂で回収する前処理をす ることが考兄られる。これについては現在検討中であ る.

ビタミンC の蓚酸への nonenzymatic な変換は, 尿 中のビタミン $\mathrm{C}$ の濃度, 尿 $\mathrm{pH}$, 尿の膀腅内滞留時間, 保存期間などに影響される ${ }^{17)}$. 尿 $\mathrm{pH}$ はわれわれの場 合, 第 1 回目の尿を容器に入れた後に塩酸を加えてい るので，問題は無い。しかし，尿が膀胼内にある間に， あるいは HPLC で測定中に変換するかもしれない。し たがって，蓄尿の 2 日前よりビタミン C 製剤などを服 用しないよらにすることが重要であろら。この注意に より，長期間の保存をする場合以外はあまり問題が無 いといら ${ }^{13)}$.

Dionex から市販されているシステムを使って， Menon ら ${ }^{18)}$ は尿中の苳酸を測った。ここでは anionexchange precolumn, 2 本の separator column, cation-exchange suppressor columnの 4 本を接続し て使用している。この方法は操作が簡単であり, 正確 であるという。しかし，1 検体の測定に30分を要する のが欠点である。

HPLC 法は茶，ビール19)などその成分が比較的単純 なものの場合にはよい測定法であることが判明した。 しかし，蓚酸はその retention time が長いために，ク ロマトグラム上シャープなピークを描かず，比較的幅 広なピークを描く。したがって，測定誤差がやや大き くなる可能性を含んでいる，今回の測定で再現性にや や問題があったのはこのためと考劣られた。 また，尿 中にはきわめて多くの物質が存在し20)，また，その組成
には大きな個人差がある。したがって，たとえば結果 のところで示したごとく，硫酸イオンが多いとこの ピークと蓚酸のピークとを分離することができない事 がありえよう。また，カラムが高価なため，経済性に 問題がある。したがって，ルーチンの臨床検査に使用 するためには前処理法などの改良が必要であろう。

茶中の蓚酸量は茶葉の量, 湯の温度, しみださせ時 間などにより左右されるであろう，今回は市販の缶入 り茶中の蓚酸量を調べた. 茶中の蓚酸量は $23 \mathrm{mg} / l \sim 88$ $\mathrm{mg} / l$, 大体 $35 \mathrm{mg} / l$ 程度であることが判明した。食物 中の蓚酸が吸収される割合は，さまざまであり ${ }^{2122) ， ま ~}$ た，同時に摄取する食物 ${ }^{23)}$ あい(腸内細菌 ${ }^{24)}$ にも影 響される。すなわち，カルシウムを同時にとれば不溶 性の蓚酸カルシウムが形成されるために苳酸の吸収は 悪くなるであろう，反対に脂肪の消化が阻害されれば 腸管内で脂肪酸がカルシウムと結合し，蓚酸と結合す べきカルシウムが減少するので，苳酸の吸収は充進す るであろら ${ }^{24)}$.さらには, 高カルシウム尿を示す場合に はカルシウムの吸収がえ進しているであろらから，腸 管中のカルシウムが減少し，吸収可能な遊離の蓚酸が 増加することも考号られる2526).このように, 食物の性 質，同時に摄取する食物の種類，摂取するヒトの状態 などにより影響されるので，一概には言えないが，イ ンスタント茶などに含まれる蓚酸は大体その $6 \%$ 吸 収される ${ }^{21)}$. したがって, 茶中に含まれるこの程度の苳 酸でも結石形成に影響する可能性は高いであろう。

尿中蓚酸排泄量に関しては厳密な意味での正常値は 設定されていない，尿中蓚酸濃度が $45 \mathrm{mg} / l$ を越える と尿中蓚酸カルシウムの結晶量が急激に上昇する ${ }^{5)}$ とも考慮すべきであろらが，1日の尿量が一定でない ので, 問題は複雑である.いくつかの報告 ${ }^{12}$ 抢よび自験 例より正常值は 1 日量 $45 \mathrm{mg}$ 以下とするのが適当と考 える. 今回の対照例の蓚酸排泄量の平均は $25.4 \mathrm{mg} /$ 日 であった. $45 \mathrm{mg} /$ 日以上の 1 例は体格が大きかった。 こ れより，1 日の蓚酸排泄量の正常範囲としては，通常 言われているょうに，45mg/日以下で良いと考えられ た ${ }^{27)}$.体格による違いを補正する目的で，1日の蓚酸排 泄量を，それぞれ，尿中クレアチニン，体重，体表面 積 ${ }^{28)}$ で割ってみると変動係数は24時間蓚酸排泄量を体 重で割ったものが最も小さい。したがって，たとえば 結石患者と対照者とを比べる場合などはこの補正值を 使うのが良いと思われる，高カルシウム尿の定義とし て, 通常は，男女別の 1 日排泄量が 300 おび250mg 以 上とするものが使われている。体重 $(\mathrm{kg})$ 当たり $4 \mathrm{mg}$ 
以上とするものもある29).これと同様に考旮れば, 高蓚 酸尿の定義として体重当たり 1 日 $0.6 \mathrm{mg}$ 以上とする のが妥当と思われる。

\section{文献}

1）伊藤晴夫：腎・尿路結石発生機序および分析法。腎 之透析, 31，23-27, 1991.

2) Finlayson, B.: Renal lithiasis in review. Clin. N. Am., 1, 181-212, 1974.

3) Ito, H., Suzuki, F., Yamaguchi, K., Nishikawa, Y. and Kotake, T.: Reduction of urinary oxalate by combined calcium and citrate administration without increase in urinary calcium oxalate stone formers. Clin. Nephrol., 37, 14-18, 1992.

4) Robertson, W.G. and Peacock, M.: The cause of idiopathic calcium stone disease. Hypercalciuria or hyperoxaluria? Nephron, 26, 105-110, 1980.

5) Hallson, P.C. and Rose, G.A.: Risk factors for urinary calcium oxalate crystals as revealed by their specific enzymatic assay. Br. J. Urol., 64, 451-457, 1989.

6) Robertson, W.G., Peacock, M., Ouimet, D., Heyburn, P.J. and Rutherford, A.: The main risk factor for calcium oxalate stone disease in man : Hypercalciuria or mild hyperoxaluria ? In Urolithiasis, Smith, L.H., Robertson, W.G. and Finlayson, B. eds., p. 3-12, Prenum Press, N.Y., 1981.

7）伊藤晴夫, 島崎 淳：蓚酸カルシウムの結晶成長 を抑制する高分子物質についての研究. 第 3 編, 苳 酸カルシウム結晶成長を抑制する高分子物質につ いて. 日泌尿会誌，69，1349-1354，1978.

8) Ito, H., Murakami, M., Miyauchi, T., Mori, I., Yamaguchi, K., Usui, T., Shimazaki, J.: The incidence of cystinuria in Japan. J. Urol., 129, 1012-1014, 1983.

9）伊藤晴夫, 中川 泰: 尿中蓚酸の測定法. 千葉医 学, 67, 37-42, 1991.

10）生間昇一郎, 本宮善恢, 常深邦彦, 平田直也, 妻谷 憲一, 森田 昇, 植村天受, 金子佳照, 守屋 昭, 吉田克法, 貴宝院邦彦, 平尾佳彦, 岡島英五郎：高 速液体クロマトグラフィー法による尿中蓚酸測定 法について。 日泌尿会誌，79，903-909，1988.

11) Millán, A., Grases, J.M. and Grases, F. : Rapid determination of urinary oxalate by highperformance liquid. chromatography. J. Chromatogr., 529, 402-407, 1990.

12）鈴木孝治, 百成智津枝：尿中蓚酸測定キット（シグ マ）の有用性. 泌尿紀要，33，794-798，1987.

13) Watts, R.W.E. : Hyperoxaluric states. in
Renal Tract Stone, Wickham, J.E.A. \& Buck, A. eds. p. 387, Churchill Livingstone, Edinburgh, 1990.

14) Wilson, D.M. and Liedtke, R.R.: Modified enzyme-based colorimetric assay of urinary and plasma oxalate with improved sensitivity and no ascorbate interference: Reference values and sample handling procedures. Clin. Chem., 37, 1229-1235, 1991.

15) Rofe, A.M., Pholenz, S.M., Bais, R. and Conyers, R.A.J.: Inhibitory effect of ascorbic acid in oxalate assays involving oxalate decarboxylase. Clin. Chem., 31, 1574-1575, 1985.

16) Inamdar, K.V., Raghavan, K.G. and Pradhan, D. S.: Five treatment procedures evaluated for the elimination of ascorbate interference in the enzymatic determination of urinary oxalate. Clin. Chem., 37, 864-868, 1991.

17) Coyle, P. and Rofe, A.M.: Improved urinary oxalate method for a centrifugal analyzer. Clin. Chem., 35, 1806, 1989.

18) Menon, M. and Mahle, C.J.: Ionchromatographic measurement of oxalate in unprocessed urine. Clin. Chem., 29, 36.9-371, 1983.

19）伊藤晴夫, 林 裕子, 山口邦雄, 西川泰世, 小竹 忠：尿路結石の排石促進あるいは再発予防にビー 儿领用をすすめてよいか. 西日泌尿, 53, 913ー916， 1991.

20) Ito, H. and Coe, F.L.: Acidic peptide and polyribonucleotide crystal growth inhibitors in human urine. Am. J. Physiol., 233, F455-F463, 1977.

21) Brinkley, L., MgGuire, J., Gregory, J. and Pak, C.Y.C.: Bioavailability of oxalate in foods. Urology, 17, 534-538, 1981.

22) Brinkley, L., MgGuire, J., Gregory, J. and Pak, C.Y.C.: A further study of oxalate bioavailability in foods. J. Urology, 144, 94-96, 1990.

23）伊藤晴夫, 山口邦雄, 西川泰世, 小竹 忠: 尿中苳 酸排泄に対するカルシウム・クエン酸併用投与の 効果. 日泌尿会誌，80，1417-1421，1989.

24）伊藤晴夫：ヒ卜腸内細菌の産生する蓚酸分解酵素 の部分精製. 日泌尿会誌，83，1395-1399，1992.

25）伊藤晴夫：堅結石の食事療法。帝京医学雑誌, 11, $331-337,1988$.

26）伊藤晴夫, 小竹 忠, 林 裕子, 鈴木文夫, 植田 健, 三浦尚人, 野村和史, 結城崇夫, 南出雅弘, 池 田良一: カルシゥム含有尿路結石患者の栄養調 査. 泌尿紀要, 38, 9-14, 1992.

27）伊藤晴夫：尿検査法。12. 有機酸 (3) シュウ酸. 検查と技術，20，146-147，1992。 
28）伊藤晴夫：蓚酸代謝異常と尿路結石. 第 2 篇 尿 中葆酸測定法の検討。日泌尿会誌，66，19-26, 1975.

29) Coe, F.L.: Treated and untreated recurrent calcium nephrolithiasis in patients with idiopathic hypercalciuria, hyperuricosuria, or no metabolic disorder. Ann. Intern. Med., 87, 404-410, 1977.

（1993年2月22日受付, 6月21日受理, 特別掲載） 